\title{
Mobilization of particulate organic matter and minerals in Zackenberg valley, Greenland
}

\section{Other Conference Item}

\section{Author(s):}

Bröder, Lisa; Hirst, Catherine; Opfergelt, Sophie; Lattaud, Julie (D); Haghipour, Negar; Eglinton, Timothy I.; Vonk, Jorien; Fouché, Julien

Publication date:

2021

Permanent link:

https://doi.org/10.3929/ethz-b-000521299

Rights / license:

Creative Commons Attribution 4.0 International

Originally published in:

EGUsphere, https://doi.org/10.5194/egusphere-egu21-11539 
EGU21-11539

https://doi.org/10.5194/egusphere-egu21-11539

EGU General Assembly 2021

(c) Author(s) 2021. This work is distributed under

the Creative Commons Attribution 4.0 License.

\title{
Mobilization of particulate organic matter and minerals in Zackenberg valley, Greenland
}

\author{
Lisa Bröder ${ }^{1}$, Catherine Hirst ${ }^{2}$, Sophie Opfergelt ${ }^{2}$, Julie Lattaud ${ }^{1}$, Negar Haghipour ${ }^{1}$, Timothy \\ Eglinton ${ }^{1}$, Jorien Vonk ${ }^{3}$, and Julien Fouché ${ }^{4}$ \\ ${ }^{1}$ Swiss Federal Institute of Technology, Zürich, Geological Institute, Department of Earth Sciences, Zürich, Switzerland \\ (lisa.broeder@erdw.ethz.ch) \\ ${ }^{2}$ Earth and Life Institute, Université catholique de Louvain, Louvain-la-Neuve, Belgium \\ ${ }^{3}$ Department of Earth Sciences, Vrije Universiteit Amsterdam, The Netherlands \\ ${ }^{4}$ LISAH, Univ Montpellier, INRAE, IRD, Institut Agro, Montpellier, France
}

Ongoing warming of the Northern high latitudes has intensified abrupt thaw processes throughout the permafrost zone. The resulting terrain disturbances are prone to release large amounts of particulate organic matter (OM) from deeper permafrost soils with thus far poorly constrained decay kinetics. Organo-mineral interactions may inhibit OM decomposition, thereby mediating the release of carbon to the atmosphere. Yet how these interactions evolve upon release and during transport along the fluvial continuum is still insufficiently understood. Here we investigate the mobilization of particulate $\mathrm{OM}$ from disturbed permafrost soils to the aquatic environment in the Zackenberg watershed in Northeastern Greenland. We collected soil samples in a thermo-erosion gully and a retrogressive thaw slump, as well as suspended solids and stream sediments along the glacio-nival Zackenberg River, including its tributaries, and a small headwater stream (Grænselv) affected by abrupt permafrost thaw. To evaluate the organic and mineral material transported, we compare mineral element and organic carbon (OC) concentrations, bulk carbon isotopes $\left({ }^{13} \mathrm{C}\right.$ and ${ }^{14} \mathrm{C}$ ), together with source-specific molecular biomarkers (plant-wax lipids and branched glycerol dialkyl glycerol tetraethers, brGDGTs) for the suspended load with their soil and sediment counterparts.

Preliminary results show large contrasts in OC concentrations as well as $\Delta^{14} \mathrm{C}$ between the glacionival river and the headwater stream, as well as between the different thaw features. The retrogressive thaw slump mobilizes relatively OC-poor material with very low $\Delta^{14} \mathrm{C}$ signatures suggesting a petrogenic contribution, while soil samples from the thermo-erosion gully had higher $O C$ concentrations and $\Delta^{14} C$ values. For Grænselv, $\Delta^{14} C$ values of the particulate $O C$ were lower close to the eroding stream bank, whereas the Zackenberg main stem displayed fairly constant $\Delta^{14} \mathrm{C}$ values, with some of the Zackenberg tributaries delivering relatively organic-rich particles low in $\Delta^{14} \mathrm{C}$.

Molecular biomarker analyses will provide additional information on specific OM sources, while Xray Diffraction (XRD) and X-ray Fluorescence (XRF) analyses on the soils, sediments and suspended mineral load will give more detailed insights into the composition of the mineral matrices. By 
combining these analytical methods, we aim to improve our understanding of the interactions between minerals and $\mathrm{OM}$ and thereby help to constrain the fate of mobilized OM upon permafrost thaw. 